\title{
ANALISIS PERAN GURU PADA PEMBELAJARAN BAHASA INGGRIS DI MASA PANDEMI COVID-19 DI SDIT AL-UMMAH CIBADAK
}

\author{
Rifa Oktaviani Jaidi ${ }^{1}$, Arsyi Rizqia Amalia ${ }^{2}$, Din Azwar Uswatun ${ }^{3 *}$ \\ ${ }^{1}$ Fakultas Keguruan Dan Ilmu Pendidikan Universitas Muhammadiyah Sukabumi \\ Jalan. R. Syamsudin, S. H. 50 Sukabumi \\ * Corresponding Author. E-mail: ${ }^{1}$ rifaoktaviani62@gmail.com
}

\begin{tabular}{|l|l|l|}
\hline Receive: 13/05/2021 & Accepted: 23/08/2021 & Published: 01/10/2021 \\
\hline
\end{tabular}

\begin{abstract}
Abstrak
Penelitian ini bertujuan untuk mendeskripsikan peran guru bahasa Inggris dan pembelajaran bahasa Inggris di kelas satu pada masa pandemi Covid-19 di SDIT Al-ummah Cibadak. Fokus penelitian mengenai peran guru pada pembelajaran bahasa Inggris yaitu guru berperan sebagai pengontrol, pendorong, fasilitator, model dan asesor. Metode penelitan menggunakan pendekatan kualitatif deskriptif. Intrumen yang digunakan yaitu wawancara dan observasi kegiatan pembelajaran. peneliti menggunakan teknik analisis data dengan mereduksi data, penyajian data dan kesimpulan. Hasil penelitian menunjukan bahwa guru bahasa Inggris di kelas satu SDIT Al-Ummah telah melaksanakan lima peran guru pada pembelajaran, yaitu guru sebagai pengontrol, pendorong, model, fasilitator dan asesor. Kendala yang dihadapi guru pada saat pembelajaran daring yaitu kurang stabilnya sinyal sehingga menghambat pembelajaran, selain itu kurangnya perhatian orangtua ketika pembelajaran berlangsung sehingga pembelajaran tidak berjalan dengan maksimal. Penelitian ini diharapkan dapat menjadi acuan bagi guru bahasa Inggris di sekolah lain untuk dapat melaksanakan pembelajaran yang lebih baik.
\end{abstract}

Kata kunci: Peran Guru; Pembelajaran Bahasa Inggris; Pembelajaran di masa pandemi

\begin{abstract}
This study aims to describe the role of English teachers and English language learning in first grade during the Covid-19 pandemic at SDIT Al-ummah Cibadak. The focus of research on the role of teachers in learning English is that teachers act as controllers, drivers, facilitators, models and assessors. The research method uses a descriptive qualitative approach. The instruments used are interviews and observation of learning activities. researchers used data analysis techniques by reducing data, presenting data and conclusions. The results showed that the English teacher in the first grade of SDIT Al-Ummah had carried out five teacher roles in learning, namely the teacher as controller, motivator, model, facilitator and assessor. The obstacles faced by teachers during online learning are the lack of stable signals that hinder learning, in addition to the lack of parental attention when learning takes place so that learning does not run optimally. This research is expected to be a reference for English teachers in other schools to be able to carry out better learning.
\end{abstract}




\section{Keywords: the role of the teacher, learning Englis Pendahuluan}

Mendidik merupakan tugas orang dewasa untuk mendewasakan seseorang, pendewasaan akan membawa pada pola pikir yang lebih maju dan selanjutnya akan menghasilkan manfaat bagi kehidupan sekitar(Sadulloh et al., 2017:72). Berdasarkan pendapat tersebut maka sudah menjadi kewajiban bagi orang dewasa untuk mendidik anak selama proses tumbuh kembang dalam rangka medewasan fisik maupun psikisnya. Lingkungan sekolah merupakan salah satu usaha dalam menciptakan dan memantau proses pendewasaan tersebut, guru dan siswa akan berinteraksi dalam sebuah lingkup belajar untuk menemukan ilmu baru hal ini dilakukan dalam rangka memberikan pengalaman belajar sekaligus memberikan bentuk dukungan sebagai bagian dari proses pendewasaan siswa(Mulyono \& Wekke, 2018:7). Berdasarkan kedua pendapat di atas, maka memberikan skill sebagai pondasi untuk melanjutkan perjuangan sebagai anak bangsa merupakan sebuah pilihan yang tepat, untuk menjalankan hal tersebut maka dibutuhkannya interaksi sosial antara guru dan siswa. Interaksi tersebut dapat dilakukan di dalam lingkungan sekolah.

Pembelajaran bahasa Inggris merupakan salah satu skill yang pada saat ini menjadi sebuah kebutuhan untuk dapat melangkah maju baik dikancah nasional maupun internasional. Bahasa Inggris merupakan bahasa penghubung di dunia ini, hampir setiap orang mengetahui bahasa Inggris baik sebagai pemula maupun sebagai native speaker (Ratminingsih, 2017:1). Bahkan syarat untuk dapat kuliah ke luar negeri adalah lulus dengan skros tertentu pad tes TOEFL. Ada empat komponen bahasa yang diterapkan pada pembelajaran Bahasa Inggris yaitu listening, speaking, reading, writing dengan mempelajari empat kemampuan dapat memberi tumpuan kepada siswa untuk dapat berkomunikasi dan menerapkan bahasa Inggris pada kehidupannya (Usman et al., 2019). Maka, berdasarkan hal tersebut pemerintah mematenkan bahasa Inggris menjadi mata pelajaran muatan lokal di sekolah dasar. Di SDIT Al-Ummah sendiri, bahasa Inggris menjadi muatan lokal pilihan kedua, hal ini learning during the pandemic

berdasarkan wawancara kepada kepala sekolah setempat. Keadaan pandemi yang belum usai membuat setiap pembelajaran mengalami perubahan durasi waktu, termasuk pada pembelajaran bahasa Inggris yakni dengan durasi 30 menit setiap pembelajarannya.

Meningkatnya penyebaran virus Covid19 membuat pemerintah mengambil tindakan tegas dalam menerapkan protokol kesehatan, penyebaran virus yang setiap harinya selalu berubah-ubah dan bermunculan varian baru seperti varian delta $(\mathrm{CNN}, 2021)$. Berdasarkan hal tersebut menggerakan pemerintah untuk mengeluarkan surat edaran mengenai belajar dari rumah, belajar dari rumah merupakan ikhtiar pemerintah dalam memutus penyebaran virus Covid-19 (Kemendikbud, 2020). Dengan edaran pemerintah yang menganjurkan belajar dari rumah membuat tenaga pendidik lebih aware dengan teknologi. Salah satu upaya yang dilakukan oleh pihak sekolah SDIT Al-Ummah adalah dengan mempersiapkan guru dan siswa untuk dapat berinteraksi secara tatap maya dengan memanfaatkan flatform online yakni zoom, google classroom, quiziz dan whatsapp.

Menurut undang-undang no. 14 tahun 2005 yang memuat tentang guru dan dosen menyatakan bahwa pendidik profesional memiliki tujuh tugas utama yakni mendidik, mengajar, membimbing, mengarahkan, melatih, menilai, dan mengevaluasi peserta didik pada jalur pendidikan usia dini, pendidikan formal, pendidikan dasar, maupun pendidikan menengah (Pusat, 2005). Berdasarkan hal tersebut maka sudah seharusnya guru dapat mengimplementasikan perannya pada pembelajaran. guru merupakan orang yang bertanggung jawab atas pendidikan siswanya, seorang guru harus memperhatikan bagaimana mendidik siswa dalam meningkatkan intelktual dan moral (Cholid, 2021:3). ciri sebagai seorang guru adalah dapat memahami materi dan menyampaikan dengan jelas kepada siswa sehingga mudah difahami, guru dapat mengatur kelas dari segi waktu, pemanfaatan media dan cara menyampaikan kepada siswa sehingga membuat suasa belajar yang menyenangkan dan bermakna, selain itu guru dapat membuat interaksi serta 
mengakrabkan diri dengan siswa tanpa menghilangkan wibawanya sebagai seorang guru dihadapan siswa (Kurniasari et al., 2019:158). Berdasarkan pernyataan tersebut guru merupakan model bagi siswa baik di dalam pembelajaran maupun diluar pembelajaran, sebagai seorang guru sudah seharusnya menunjukan perilaku yang dapat dicontoh oleh siswa. karena pada dasarnya siswa akan lebih melihat perilaku guru hal tersebut dapat memicu hal baik jika guru memberi contoh baik dan akan terjadi hal buruk jika guru memberi contoh buruk kepada siswa.

Menurut (Ratminingsih, 2017:42-43) bahwa peran guru dalam pembelajaran bahasa Inggris ada lima yaitu guru sebagai pengontrol, pendorong, penilai, sumber, tutor dan penasehat. Sedangkan menurut (Sukitman et al., 2020:94-95) ada empat peran guru yang harus diperhatikan dan diterapkan pada pembelajaran di masa pandemi yaitu guru sebagai motivator, fasilitator, transformasi, dan adaptasi. Berdasarkan kedua pendapat tersebut peneliti hendak meneliti lima peran guru pada pembelajaran bahasa Inggris yaitu peran guru sebagai pengontrol, pendorong, fasilitator, model, dan asesor selama masa pandemi Covid19.

\section{Metode}

Jenis penelitian ini menggunakan jenis metode penelitian deskriptif kualitatif. Menurut Sugiyono (2016:295) menyatakan bahwa penelitian kualitatif merupakan sebuah penelitian yang menghasilkan teori baru, bahkan dalam proses penelitian tidak dapat ditentukan secara pasti karena ketika langsung ke lapangan akan ada kemungkinan perubahan teori sesuai dengan yang ditemukan ketika penelitian berlangsung. Tentunya hal tersebut mengisyaratkan bahwa penelitian kualitatif bersifat fleksibel dapat berubah sesuai dengan kenyataan yang ada di lapangan karena jenis penelitian ini mengandalkan sebuah proses yang alamiah. penelitian ini akan berfokus mengenai pengambilan data secara alamiah dan akan dilaporkan dalam bentuk kata deskriptif.

Penelitian dilaksanakan di SDIT AlUmmah Cibadak, peneliti melaksanakan penelitian di semester genap tepatnya di kelas satu sekolah dasar tersebut. Subjek penelitian merupakan guru bahasa Inggris dan siswa di kelas satu SDIT Al-Ummah. penulis menggunakan teknik sampel jenuh. Peneliti menggunakan instrumen penelitian berupa lembar wawancara dan observasi, dimana peneliti membuat terlebih dahulu kisi-kisi dari instrumen wawancara dan observasi tersebut dengan memasukan aspek-aspek terkait penelitian yang perlu diungkap untuk mendapatkan data secara nyata di lapangan.

Setelah peneliti mempersiapkan instrumen penelitian, peneliti mulai mengambil data pada pihak terkait yaitu guru bahasa Inggris dan siswa di kelas satu. Setelah mendapatkan data, peneliti mulai mengolah data. Teknik pengolahan data yang digunakan berdasarkan Miles dan Huberman (Sugiyono, 2016:401) yaitu melalui tiga tahap pelaksanaan reduksi data yang merupakan tahapan pertama, dimana peneliti meruduksi atau memilah dan memilih data yang dapat memberika jawaban dan melengkapi data dalam penelitian peran guru dalam pembelajaran bahasa Inggris di masa pandemi Covid-19 di SDIT Al-Ummah Cibadak, display data tahap kedua ini dilakukan peneliti untuk menyajikan data dalam bentuk tabel maupun grafik yang kemudian akan disajikan dalam bentuk laporan penelitian peran guru dalam pembelajaran bahasa Inggris di masa pandemi Covid-19 di SDIT Al-Ummah Cibadak, dan yang terakhir adalah verifikasi data yaitu peneliti dapat menyimpulkan dari data yang telah dikumpulkan yang kemudia akan menjadikan data tersebut sebagai rumusan masalah dari konteks penelitian terkait peran guru dalam pembelajaran bahasa Inggris di masa pandemi Covid-19 di SDIT Al-Ummah Cibadak.

\section{Hasil dan Pembahasan}

Hasil wawancara pada guru bahasa Inggris mengenai peran guru dalam pembelajaran bahasa Inggris menunjukan bahwa persiapan pembelajaran di masa pandemi Covid-19 telah disesuaikan dengan pembelajaran daring dan dalam penyusuna RPP masih sama seperti biasanya, hanya format RPP dan kurikulum darurat yang menjadi perubahan 
pada perencanaan pembelajaran. Namun, guru belum rutin dalam pembuatan RPP sebelum pembelajaran berlangsung. Guru berperan sebagai fasilitator seperti mempersiapkan bahan ajar untuk pembelajaran daring dalam bentuk gambar maupun audio visual. Pemilihan media disesuaikan dengan kondisi dan karakteristik siswa karena pada umumnya media adalah alat bantu yang memudahkan guru dalam menyampaikan materi supaya mudah difahami oleh siswa. pemiliham metode maupun strategi disesuaikan dengan kebutuhan dan karakteristik siswa, guru menggunakan metode ceramah, tanya jawab dan penugasan dalam pembelajaran daring. Selama pembelajaran berlangsung guru berupaya dalam membangkitkan semangat anak dengan melibatkan anak dalam pembelajaran.

Peran guru sebagai model pada pembelajaran seperti mengingatkan kepada siswa untuk tetap menjaga Kesehatan dan menerapkan protokol kesehata di rumah, dalam hal ini guru meminta siswa untuk mendokumentasikan kegiatan tersebut. Guru menunjukan rasa antusiasme dan ekspresi yang ceria saat menyampaikan pembelajaran untuk menarik minat belajar siswa. Peran guru sebagai pendorong seperti, saat pembelajaran berlangsung dan fokus siswa mulai menurun guru akan mengingatkan siswa untuk tetap fokus pada pembelajaran guru juga mengapresiasi siswa dengan perkataan singkat dalam bahasa Inggris yang bermakna positif seperti you are excellent, good job dan lainnya. mendorong siswa untuk aktif bertanya pada pembelajaran dengan memberikan kesempatan bertanya kepada siswa. peran guru sebagai asesor seperti memberikan evaluasi kepada siswa baik secara langsung seperti memberi pertanyaan terkait pembelajaran yang disampaikan maupun secara tidak langsung dengan memberikan quiz melalui platform online quiziz atau memberikan tugas untuk dikerjakan di rumah. Dalam proses pengumpulan tugas guru akan meminta dokumentasi hasil dari tugas tersebut berbentuk foto atau video dan dikirimkan melalu whatsapp pribadi guru.

Pembelajaran online yang sebelumnya merupakan sesuatu yang asing pada dunia pendidikan kini menjadi sesuatu yang biasa untuk dilakukan. Pembelajaran dalam jaringan yang telah terlaksana selama satu tahun ini tentu tidak lepas dari kendala-kendala yang menyertainya. Kendala yang dirasakan oleh guru pada pembelajaran daring adalah kurang stabilnya sinyal sehingga mengganggu proses pembelajaran, guru juga kesulitan dalam menilai proses belajar siswa karena guru tidak dapat melihat secara langsung pembelajaran yang dilakukan di rumah selain itu, guru kesulitan dalam memvariasikan pembelajaran karena keterabatasan guru dan siswa mengenai pembelajaran berbasis teknoliogi sehingga membutuhkan edukasi ulang untuk guru dan juga untuk siswa. kendala yang terjadi pada siswa saat pembelajaran berlangsung dari sudut pandang guru yaitu kurang stabilnya sinyal di daerah rumah masing-masing siswa, hal ini menghambat ketika proses penyampaian materi sehingga guru harus mengulang-ngulang penjelasannya, siswa juga kurang kondusif pada saat pembelajaran seperti hilangnya fokus siswa karena tingkah teman-temannya di depan kamera hal ini menyebabkan beberapa anak mengobrol maupun saling menanggapi satu sama lain di dalam kelas online. kurangnya dampingan dari pihak keluarga pada saat pembelajaran online berlangsung sehingga siswa sulit untuk dikondisikan selama pembelajaran dan ada siswa yang ikut dalam kelas online tapi selama pembelajaran berlangsung microphone maupun videonya dimatikan sampai pembelajaran selesai.

Hasil observasi pada pembelajaran bahasa Inggris di masa pandemi Covid-19 di kelas satu SDIT Al-Ummah menunjukan peran guru sebagai fasilitator bahwa guru dalam 
merancang RPP memperhatikan penjabaran kompetensi inti dan kompetensi dasar pada indikator, skenario pada pembelajaran sudah dirinci sesuai dengan ketetapan penyusuna RPP baru denga tiga komponen di dalamnya yaitu tujuan pembelajaran, langkah pembelajaran dan assesment pembelajaran. penilaian yang dilakukakn oleh guru telah mencakup pada tiga aspek yaitu sikap, pengetahuan, dan keterampilan. Perangkat penilaian sudah lengkap berikut dengan instrumen penilaian, kunci jawaban serta pedoman penskoran. Pada pelaksanaan pembelajaran guru melaksanakan tiga kegiatan pembelajaran yaitu pembukaan, inti dan penutup.

peran guru sebagai pengontrol dapat mengkondisikan siswa dan mengontrol siswa dengan memberikan aturan-aturan di dalam kelas online. ada masanya siswa sulit untuk dikondisikan, pada kondisi ini guru akan memberikan ice breaking untuk mengembalikan fokus siswa. guru menyajikan materi secara berurutan sehingga guru dapat mengontrol durasi waktu pembelajaran. peran guru sebagai pendorong ditunjukan pada saat guru memberikan lagu-lagu diawal pembelajaran untuk mendorong rasa antusias siswa dan memberikan motivasi mengenai tujuan dalam belajar bahasa Inggris. guru juga memberikan pertanyaan produktif untuk menggiring opini siswa menemukan sendiri mengenai materi yang hendak dipelajarinya. Guru merelevansi materi pembelajaran dengn kehidupan sehari-hari untuk memberikan pemahaman yang sederhana kepada siswa, guru juga menggiring siswa untuk dapat menyimpulkan sendiri di akhir sesi pembelajaran. guru sebagai fasilitator ditunjukan pada saat guru mempersiapkan pembelajaran, pada pembelajaran guru memberi tahukan mengenai acuan pembelajaran pada hari tersebut. Guru juga memfasilitasi siswa dengan menyesuaikan bahan ajar berbasis TPACK (Technological, pedagogical, content knowledge), seperti guru dapat mengoprasikan aplikasi zoom secara mandiri sebagai penghubung antara guru dan siswa, guru membuat media pembelajaran berbasis power point dalam bentuk gambar maupun audio visual. Guru juga menyesuaikan model dan metode yang digunakan, pada pembelajaran daring ini guru menggunakan metode ceramah dan tanya jawab kepada siswa.

peran guru sebagai asesor ditunjukan pada saat guru melakukan assesment for learning dengan memberikan pertanyaan kepada siswa secara klasikal maupun perorangan. Selain itu guru juga melaksanakan evaluasi yang berorientasi pada pencapaian tujuan dengan menggunak platform quziz diakhir pembelajaran. peran guru sebagai model ditujukan pada saat guru menyampaikan materi dengan antusian dan menampilkan wajah yang ceria, guru juga menggunakan bahasa yang santun saat berkomunikasi bersama siswa, guru menampilkan dirinya sebagai model dengan percaya diri dalam menyampaikan materi dan memberi perhatian ketika siswa mengutarakan pendapatnya. Selain itu, guru telah mengintegrasikan pembelajaran dengan nilai-nilai islami seperti saat materi membahas tema binatang peliharaan, guru menjelaskan bahwa anjing yang dalam bahasa Inggris adalah $\operatorname{dog}$ merupakan salah satu binatang yang sering dipelihara. Binatang ini merupakan binatang yang diharamkan dalam islam dan bagi umat muslim tidak dianjurkan untuk memelihara binatang tersebut.

Berdasarkan hasil wawancara dan observasi menunjukan bahwa peran guru bahasa Inggris kelas satu di SDIT Al- Ummah sudah diterapkan dengan baik. Pembelajaran bahasa Inggris di SDIT Al-Ummah tetap berjalan dengan baik meski pembelajaran sepenuhnya belajar dari rumah. Pembelajaran bahasa Inggris di SDIT Al-Ummah di masa pandemi Covid-19 dari awal tahun 
pembelajaran lebih mendominasi menggunakan aplikasi zoom. Guru berinteraksi langsung bersama siswa di dalam kelas online. Guru bahasa Inggris mengisi kelas selama 30 menit dalam satu kali pertemuan. Pada kesempatan bertatap maya dengan peserta didik guru dapat melihat bagaimana proses anak dalam mendapatkan materi dan seperti apa respon peserta didik dalam mengikuti pembelajaran bahasa Inggris pada pembelajaran online. Berdasarkan hasil observasi dan wawancara guru telah menjalankan lima peran di dalam kelas, yaitu:

\section{Guru sebagai fasilitator}

Guru sebagai fasilitator, guru memfasilitasi siswa selama pembelajaran berlangsung baik secara fisik maupun non fisik. Hal tersebut selaras dengan apa yang kemukakan oleh Safitri \& Dafit (2021:1361) bahwa dalam memberikan pelayanan yang baik secara langsung maupun tidak langsung merupakan peran guru sebagai fasilitator di dalam kelas, untuk menjalankan peran sebagai fasilitator hendaknya guru dapat melihat dan menganalisis kebutuhan siswa dalam pembelajaran sehingga dapat mempermudah guru dalam menyampaikan materi dan mudah diterima oleh siswa. Pendapat lain menyatakan bahwa guru sebagai fasilitator memiliki banyak arti yang menunjukan dirinya sebagai jembatan penghubung antara ilmu dan siswa, guru hendaknya dapat menjadikan siswa sebagai student center sehingga pembelajaran antar teman sebaya akan terjalin, guru juga menyediakan media maupun materi yang sesuai dalam pembelajaran guna mempermudah berlangsungnya proses pembelajaran (Yus \& Sari, 2020:86).

Pernyataan tersebut selaras dengan hasil penelitian yang telah dilakukan, guru menunjukan perannya sebagai fasilitator dalam merencanakan pembelajaran. Namun, guru belum konsisten dalam membuat RPP berdasarkan aturan pemerintah mengenai sistematika pembuatan RPP. Guru membuat RPP pada catatan kasar sebagai acuan berjalannya pembelajaran. guru merancanakan pembelajaran berbasis TPACK, seperti membuat media pembelajaran dari power point dalam bentuk gambar maupun audio visual untuk mempermudah proses penyampaian materi. Guru memilih media maupun sumber belajar yang dibutuhkan oleh siswa, seperti guru menggunakan aplikasi zoom dalam pembelajaran yang setiap siswa sudah dapat mengoperasikannya, guru juga memfasilitasi siswa dengan memberikan kesempatan bertanya diakhir sesi pembelajaran.

\section{Guru sebagai pengontrol}

Guru sebagai pengontrol berperan untuk mengontrol keadaan kelas seperti dapat menguasai kelas baik dari segi materi maupun siswa sehingga pembelajaran dapat berjalan dengan efektif, mengontrol kelas bagi seorang guru termasuk bagaimana guru mengendalikan suasana kelas dan bertanggung jawab mengenai terlaksananya pembelajaran (Ratminingsih, 2017:43). Pendapat tersebut selaras dengan hasil penelitian yang didapat bahwa guru bahasa Inggris telah menjalankan perannya sebagai pengontrol. Terwujud saat guru dapat menyesuaikan metode atau strategi dengan karakter peserta didik. Guru juga dapat menyampaikan pembelajaran secara berurutan dan dalam prosesnya guru melibatkan siswa untuk berinteraksi, guru memberikan peraturan kelas kepada siswa untuk memberi penekanan mengenai hal apa saja yang boleh dan tidak boleh dilakukan ketika pembelajaran berlangsung. dalam proses pembelajaran ketika suasana belajar mulai jenuh dan konsentrasi siswa menurun guru mengajak siswa untuk melakukan ice breaking bersama dan hal ini efektif untuk mengembalikan fokus siswa pada pembelajaran. pemberian ice breaking singkat ini selaras dengan apa yang dikemukakan oleh Fauzan \& Aripin (2019:18) bahwa ice breaking merupakan kegiatan singkat yang dilakukan di 
dalam pembelajaran yang berguna untuk mengembalikan konsentrasi belajar pada siswa dengan memberikan rasa semangat dan ceria kepada siswa, sehingga pembelajaran dapat berjalan dengan menyenangkan dengan harapan dapat mencapai tujuan pembelajaran yang telah ditentukan.

\section{Guru sebagai pendorong}

Peran guru sebagai pendorong yakni memberikan dukungan kepada siswa dengan mengapresiasi usaha belajar yang dilakukan siswa di dalam kelas dengan kata-kata yang positif seperti excellent atau good job, sehingga siswa merasa dirinya telah dihargai hal ini akan berdampak baik pada proses pembelajaran dan berujung terjadinya pembelajaran yang efektif dan menyenangkan (Sabaniah et al, 2021:43). Pendapat lain menyatakan bahwa pemberian dorongan dan motivasi pada saat pembelajaran merupakan pemberian stimulus kepada siswa yang akan mengahasilkan respon yang baik pada pembelajaran, memberi dorongan juga salah satunya untuk menggriring siswa menemukan cara belajar yang tepat sehingga siswa akan mudah memahami materi yang sedang dipelajarinya (Ora \& Mursalim, 2021:48).

Berdasarkan pendapat di atas hasil penelitian menunjukan bahwa guru dapat menerapkan perannya sebagai pendorong pada pembelajaran bahasa Inggris di kelas satu SDIT Al-Ummah ketika ada unit pada pembelajaran bahasa Inggris yang meminta siswa untuk "look and write, listen and talk, say and chant, read and circle" guru menunjukan perannya sebagai pendorong dalam pembelajaran. Guru mendorong siswa dengan dorongan verbal yang positif dalam pembelajaran seperti mengingatkan siswa untuk fokus dan memberikan pujian atas usaha yang dilakukan oleh siswa. guru juga memberi pengertian kepada siswa mengenai tujuannya dalam belajar bahasa Inggris untuk menumbuhkan keinginan kuat dalam mempelajarinya. guru juga memberikan menjelaskan materi dengan mengaitkannya pada kehidupan sehari-hari agar mudah difahami siswa. selain itu, guru mendorong siswa untuk menyimpulkan di akhir sesi pembelajaran.

4. Guru sebagai model

Menjadi seorang guru berarti mempertanggung jawabkan pendidikan siswa sepenuhnya dari keterampilan hingga akhlaknya, maka guru harus menjadi role model bagi siswa dalam pembelajaran maupun di luar pembelajaran karena siswa akan melihat perilaku guru dalam perbuatan maupun perkataanya alangkah lebih baiknya jika guru dapat menjaga perilakunya dihadapan siswa (Lian et al, 2020:928). Pendapat lain menyatakan bahwa guru dalam berprilaku dalam lingkungan pendidikan maupun di luar lingkungan pendidikan hendaknya memperhatikan setiap tindakan yang hendak dilakukannya, seorang guru dalam bertindak harus sesuai dengan norma-norma yang diantu oleh masyarakat, guru harus dapat bersikap sesuai dengan nilai-nilai pancasila karena guru diharapkan dapat menjadi contoh dan suri tauladan bagi siswa (Wardan, 2019:181). Menurut Marjuni \& Suban (2020:16) menyatakan bahwa guru dalam berperan sebagai model dalam pembelajaran tidak hanya dengan menunjukan tindakan yang baik dan perkataan yang sopan namun juga meliputi dengan bagaimana guru dapat menunjukan citranya sebagai guru yang profesional dalam menyampaikan materi kepada siswa dan menunjukan diri yang berwawasan luas dengan memunculkan pemikiran baru dalam pembelajaran sehingga membuat suasa belajar lebih menyenangkan dan efektif dalam penyampaiannya.

Pernyataan di atas selaras dengan hasil penelitian yang didapat bahwa guru bahasa Inggris telah menjalankan perannya sebagai model dengan baik. Guru dapat menjelaskan pembelajaran dan mengaitkan dengan nilai- 
nilai islam, seperti ketika pembahasan tema binatang peliharaan guru menjelaskan bahwa binatang anjing yang dalam bahasa Inggrinya adalah $d o g$ merupakan binatang yang diharamkan untuk dipelihara oleh ummat islam karena najis besar yang terdapat dalam air liurnya. Guru juga mengingatkan siswa untuk menjaga kesehatan dan menerapkan protokol kesehatan di rumah. Selama proses pembelajaran guru menyampaikan materi dengan ceria dan bersemangat serta percaya diri saat memaparkannya, hal ini menunjukan bahwa guru menguasai materi dengan baik. Sehingga pembelajaran dapat terlaksana dengan baik dan menyenangkan.

\section{Guru sebagai asesor}

Guru sebagai asesor merupakan guru yang memberi evaluasi pada pembelajaran untuk mengetahui sejauh mana siswa dapat menerima materi yang telah disampaikan kemudian guru akan mengoreksi jawaban dari siswa yang kemudian dikumpulkan untuk diperbaiki dan ditindak lanjuti untuk menemukan solusi yang tepat sehingga tercapaianya tujuan pembelajaran (Ratminingsih, 2017:43). Pendapat lain menyatakan bahwa guru berperan sebagai asesor berfungsi untuk mengumpulkan informasi mengenai ketercapaian hasil belajar siswa, hal ini dilakukan guru untuk mengetahui seberapa banyak siswa yang dapat memahami materi yang telah diajarkan di dalam kelas, sehingga guru dapat menentukan tindakan yang tepat dalam menyelesaikan masalah yang dihadapi (Normawati et al., 2019:17).

Berdasarkan pendapat tersebut penelitian menunjukan bahwa guru telah berperan sebagai asesor dalam pembelajaran bahasa Inggris. hal tersebut terwujud ketika guru mengevaluasi siswa secara langsung dengan memberi pertanyaan mengenai materi yang telah disampaikan secara individu maupun klasikal. Guru juga pada beberapa kesempatan memafaatkan flatform online seperti quiziz untuk memberikan evaluasi pembelajaran kepada siswa. guru juga memberikan tugas untuk dikerjakan di rumah, proses pengumpulan tugas dilakukan secara daring dengan mengirimkan dokumentasi berupa foto maupun video melalui aplikasi whatsapp dan dikirim ke whatsapp pribadi guru bahasa Inggris atau melalu platform google classroom.

\section{Simpulan}

Peran guru pada pembelajaran bahasa Inggris di kelas satu SDIT Al-Ummah telah terlaksana selama kegiatan pembelajaran. Adapun peran yang dianalisis dan muncul adalah peran guru sebagai pengontrol, pendorong, model, fasilitator dan asesor. Guru menerapkan peran fasilitator ketika menyiapkan dan menyediakan bahan ajar dan media pembelajaran, guru juga memfasilitasi siswa dengan memberikan kesempatan untuk bertanya. Namun, untuk pembuatan RPP guru belum dapat melaksanakannya secara konsisten, guru hanya membuat catatan kasar sebagai acuan dalam proses pembelajaran. guru menerapkan peran sebagai pengontrol yakni saat guru dapat mengontrol penyampaian materi secara berurutan dan guru dapat mengendalikan kelas dengan baik seperti memberi ice breaking ketika siswa mulai merasa bosan dan kurang kondisif, guru juga memberikan peraturan diawal pembelajaran sehingga pembelajaran dapat berjalan dengan efektif.

Guru menjalankan perannya sebagai pendorong ketika guru menggiring siswa untuk menyimpulkan pembelajaran, guru juga memotivasi siswa mengenai tujuan dalam mempelajari bahasa Inggris, sehingga siswa dapat mengetahui tujuannya dalam belajar bahasa Inggris. guru menjalankan perannya sebagai model pada saat guru memberikan materi dengan ceria, percaya diri, dan menggunakan perkataan yang sopan dalam menjelaskan materi tersebut, guru juga menanggapi pendapat siswa dengan baik serta mengingatkan siswa untuk menjaga kebersihan dan menerapkan protokol kesehatan walaupun berada di rumah. Guru menjalankan perannya sebagai asesor ketika guru memberikan 
pertanyaan kepada siswa mengenai pembelajaran yang telah disampaikan baik secara individu maupun klasikal, guru juga terkadang memberikan evaluasi melalui platform online quiziz kepada siswa. proses pengumpulan tugas dilakukan secara online melalui whatsapp atau google classroom.

\section{Daftar Pustaka}

Holid, N. (2021). Menjadi Guru Profesional. S emarang: CV Presisi Cipta. Retrieved fr om https://books.google.co.id/books?hl $=$ en $\& 1 \mathrm{r}=\& \mathrm{id}=8 \_$wdEAAAQBAJ\&o $=\mathrm{fn}$ $\mathrm{d} \& \mathrm{pg}=\mathrm{PT} 4 \& \mathrm{dq}=$ engertian + guru\&ots $=\mathrm{r}$ MUeGHzbMG\&sig=jCChvHZAb xoich eZn1RoQ5 Odk\&redir_esc $=y \# v=$ onepag $\mathrm{e} \& \mathrm{q}=$ pengertian guru $\& \mathrm{f}=$ false.

CNN. (2021). Positif Covid 19 Melonjak 12. 906 Kasus, Kematian Naik 248. Retrieve d 23 Juni 2021 from https://www.cnnind onesia.com/nasional/2021061915163920-656637/positif-covid-19-melonjak12906-kasus-kematia-naik-248.

Fauzan, G. A., \& Aripin, U. (2019). Penerap an Ice Breaking dalam Pembelajaran $M$ atematika untuk Meningkatkan Rasa Per caya Diri Siswa VIII B SMP Bina Harap an Bangsa. JPMI (Jurnal Pembelajaran Matematika Inovatif), 2(1), 18. Retrieve $\mathrm{d}$ from https://www.journal.ikipsiliwangi .ac.id/index.php/jpmi/article/view/2385/ 960.

Kemendikbud. (2020). Surat Edaran No. 4 ta hun 2020 Tentang Pelaksanaan Pendidik an dalam Masa Darurat CoronaVirus (COVID-19). Jakarta : KEMENDIKBUD (p. 2).

Kurniasari, N., Kusdiwelirawan, A., \& Hartini, T. I. (2019). Menganalisis Kebij akan Profesional Pendidik Mata Pelajaran Fisika Pada Sekolah Muham madiyah Jakarta. SINAFI (Seminar Nasional Fisika), 1(1), 158.

Lian, B., Kristiawan, M., Ammelia, D., Primas ari, G., Anggung, M., \& Prasetyo, M. (2 020).Teachers' Modelin Building Studen ts' Character. Journal of Critical Review s, 7(14), 928. Retrieved from https://doi. org/10.31838/jcr.07.14.165.
Marjuni, A., \& Suban, A. (2020). Profil Guru Harapan Masa Depan. Al Asma : Journ al of Islamic Education, 2(1), 16. Retrieved from https://doi.org/10.242 52/asma.v2i1.13361.

Mulyono, \& Wekke, I. S.(2018). Strategi Pem belajaran di Abad Digital. Yogyakarta: Gawe Buku.

Normawati, S., Anwar, S., \& Indramaya, S.(20 19). Etika \& Profesi Guru (N. I. Zelia (e d.);ke 1). Tembilahan: PT. Indragiri Dot Com. Retrieved from https://play.google. com/books/reader?id=dlDGDwAAQBA $\mathrm{J} \& \mathrm{hl}=\mathrm{id} \& \mathrm{pg}=\mathrm{GBS} . \mathrm{PP} 4$.

Ora, H. O. koba, \& Mursalim, M. (2021). Pera nan Guru terhadap Motivasi Belajar IPS Siswa Kelas V SD Inpres 51 Kabupaten Sorong. Jurnal Papeda: Jurnal Publikasi Pendidikan Dasar, 3(1), 48.Retrieved fr om https://doi.org/10.36232/jurnalpendi dikandasar.v3i1.759.

Pusat, P. (2005). Undang Undang (UU) tentan g Guru dan Dosen Nomor 14. Jakarta: In Dewan Perwakilan Rakyat Indonesia (p. 2). DPR RI.Retrieved from https://ww w.google.com/url? sa $=$ t\&rct $=\mathrm{j} \& \mathrm{q}=\&$ esrc $=\mathrm{s} \&$ source $=$ web $\& \mathrm{~cd}=1 \& \mathrm{cad}=$ rja\&ua $\mathrm{t}=8$ \&ved=2ahUKEwjWxrKeif7eAhVYfysK HcHWAOwQFjAAegQICRAC\&url=htt ps $\% 3 \mathrm{~A} \% 2 \% 2 \mathrm{Fwww} .0 j k$.go.id $\% 2 \mathrm{Fid} \% 2$ Fkanal\%2Fpasar modal $\% 2$ Fregulasi $\% 2 \mathrm{~F}$ undang undang\%2FDocuments $\% 2 \mathrm{FPage}$ s\%2Fundang-undang-nomo.

Ratminingsih, N. M. (2017). Metode Dan Strat egi Pembelajaran Bahasa Inggris.Depok : PT Rajagrapindo Persada.

Sabaniah, S.,Ramdhan, D. F., \& Rohmah, S. K. (2021). Peran Guru dalam Pelaksana an Pembelajaran Jarak Jauh di Tengah Wabah Covid - 19. Edunesia : Jurnal Ilm iah Pendidikan, 2(1), 43. Retrieved from https://doi.org/10.51276/edu.v2i1.77.

Sadulloh, U., Robandi, B., \& Muharram, A. (2 017). PEDAGOGIK (Ilmu Mendidik). B andung: CV ALFABETA.

Safitri, V., \& Dafit, F. (2021). Peran Guru dalam Pembelajaran Membaca dan Menulis Melalui Gerakan Literasi di Sek olah Dasar. Jurnal Basicedu, 5(3), 1361. Retrieved from https://jbasic.org/index. 
$\mathrm{php} / \mathrm{basicedu} / \mathrm{article} / \mathrm{view} / 938$.

Sugiyono. (2016). Metode Penelitian Pendidikan Pendekatan Kuantitatif, Kualitatif, $R \& D$ (ke-23). Bandung: CV Alfabeta.

Sukitman, T., Yazid, A., \& Mas'odi. (2020).P eran Guru Pada Masa Pandemi Covid 1 9. In Prosiding Diskusi Daring Tematik Nasional (pp. 94-95). STKIP PGRI Sumenep.

Usman, H., Utami, N. C. M., \& Fajarianto, O. (2019). Model of English Teaching Materials fo Elementary Schools Based on Contextual Approaches. Jurnal Tekno logi Pendidikan, 21(3), 232.

Wardan, K. (2019). Guru Sebagai Profesi. Yo gyakarta: Deepublish. Retrieved from htt ps://books.google.co.id/books?hl=en\&lr $=\& \mathrm{id}=\mathrm{DHmfDwAAQBAJ} \& \mathrm{oi}=\mathrm{fnd} \& \mathrm{pg}=$ PR5\&dq $=$ pengertian + guru\&ots $=$ hu2SDv tggy\&sig $=\mathrm{xXS39uurm0jbwaVtNufWqw}$ 4QHmE\&redir_esc $=y \# v=$ onepage $\& \mathrm{q}=\mathrm{p}$ engertian guru $\& \mathrm{f}=$ false

Yus, A., \& Sari, W. W. (2020). Pembelajaran Di Pendidikan Usi Dini (2nded.). Jakarta : Kencana (Divisi Prenadamedia Group). Retrieved from https://www.google.co.i d/books/edition/Pembelajaran_Di_Pendi dikan_Usi_Dini/7p7_DwAAQBAJ?hl=i $\mathrm{d} \& \mathrm{gbpv}=1$ 